\title{
Using theory of constraints and $A B C$ to enhance cost calculations at DuoGraphic B.V. : a case study
}

Citation for published version (APA):

Vergauwen, P. G. M. C. (2002). Using theory of constraints and ABC to enhance cost calculations at DuoGraphic B.V. : a case study. METEOR, Maastricht University School of Business and Economics. METEOR Research Memorandum No. 040 https://doi.org/10.26481/umamet.2002040

Document status and date:

Published: 01/01/2002

DOI:

10.26481/umamet.2002040

Document Version:

Publisher's PDF, also known as Version of record

\section{Please check the document version of this publication:}

- A submitted manuscript is the version of the article upon submission and before peer-review. There can be important differences between the submitted version and the official published version of record.

People interested in the research are advised to contact the author for the final version of the publication, or visit the DOI to the publisher's website.

- The final author version and the galley proof are versions of the publication after peer review.

- The final published version features the final layout of the paper including the volume, issue and page numbers.

Link to publication

\footnotetext{
General rights rights.

- You may freely distribute the URL identifying the publication in the public portal. please follow below link for the End User Agreement:

www.umlib.nl/taverne-license

Take down policy

If you believe that this document breaches copyright please contact us at:

repository@maastrichtuniversity.nl

providing details and we will investigate your claim.
}

Copyright and moral rights for the publications made accessible in the public portal are retained by the authors and/or other copyright owners and it is a condition of accessing publications that users recognise and abide by the legal requirements associated with these

- Users may download and print one copy of any publication from the public portal for the purpose of private study or research.

- You may not further distribute the material or use it for any profit-making activity or commercial gain

If the publication is distributed under the terms of Article $25 \mathrm{fa}$ of the Dutch Copyright Act, indicated by the "Taverne" license above, 


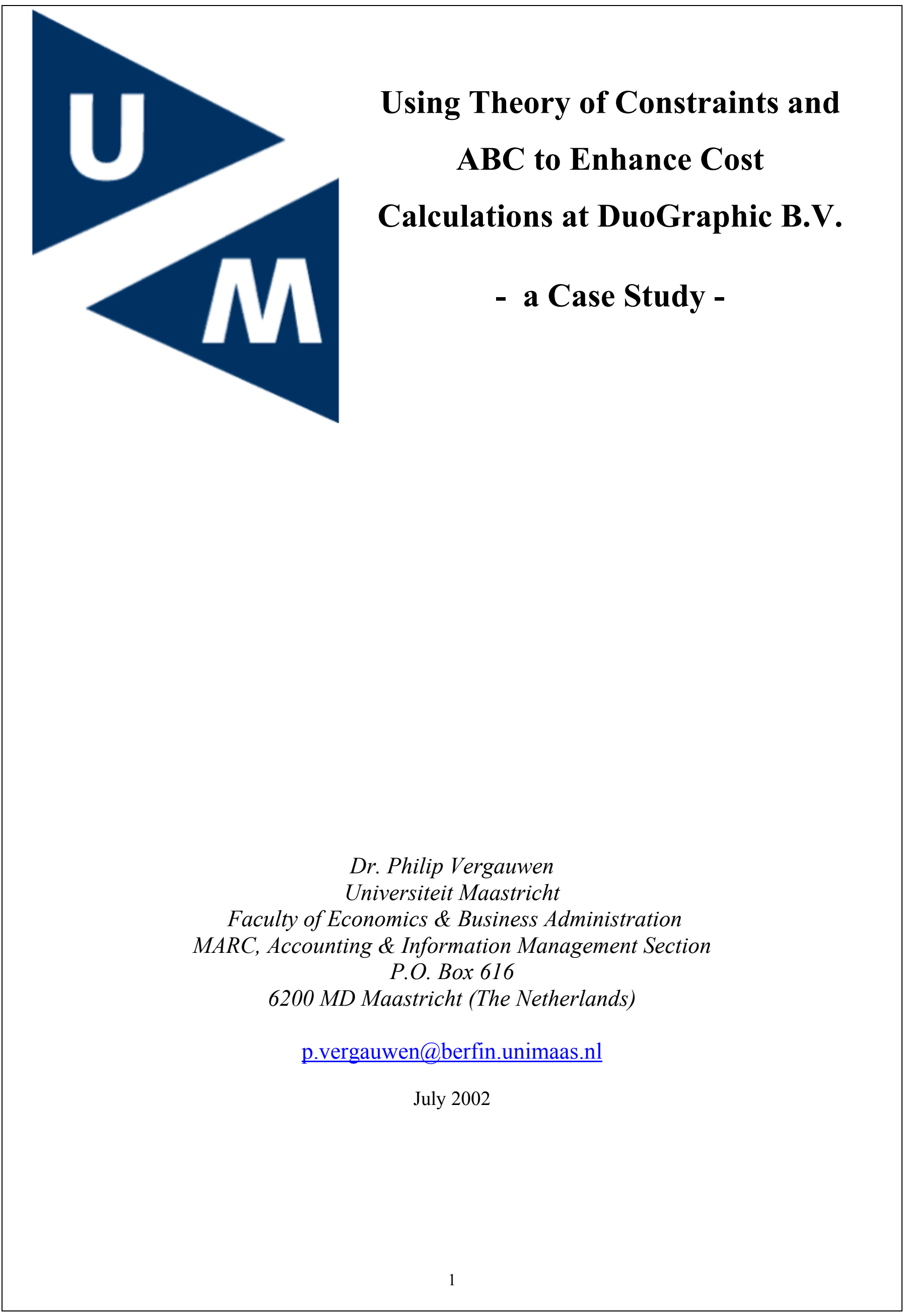




\section{$\underline{\text { Abstract }}$}

This case focuses on the application of management accounting techniques such as linear programming and regression analysis in the framework of activity-based costing and the theory of constraints. Students are invited to transform technical production data (process map) into data that is necessary for the ABC cost calculations. Furthermore, given the technical production data, students learn how to assess the possibilities to enhance profitability and how to transform ABC and TOC analysis into management information.

\section{Introduction: Company and Industry Background}

Duographic B.V. is a custom screen printing business whose major customers are local high schools, youth organizations, sporting clubs, and small businesses. The company produces a variety of T-shirts, silk screened in as many as six different colours. There is virtually no entry barrier to the screen printing business because the start-up costs are small and the printing technique is one that is learned easily. Consequently, the business is highly competitive.

In its fourth year of operations, DuoGraphic B.V. wants to start with activity-based cost management $(\mathrm{ABCM})$ and would like to integrate this cost system with insights of the theory of constraints (TOC). A first step in this implementation process entailed an analysis of the activities that were necessary in the custom screen printing business. The company's owner and CEO, Mr. van Schenkel, identified the following activities:

- Production labour;

- Machines;

- Set-ups;

- Quality control;

- Reclaiming;

- Purchasing and

- Sales and marketing.

Mr. van Schenkel also analysed the income statement for the past ended in order to reclassify the expenses (totalling ع128.970) from the traditional account classification to an activity-based costing (ABC-) classification. Tracing to activities was accomplished through interviews and an analysis of the accounting records together with all types of supporting documents. The following breakdown was the result of this tracing to activities: 


\begin{tabular}{|lr|}
\hline \multicolumn{2}{c|}{$\begin{array}{c}\text { Exhibit A } \\
\text { DuoGraphic B.V. } \\
\text { Tracing Expenses to Activities }\end{array}$} \\
Activity & $\boldsymbol{\varepsilon}$ \\
\hline Production labour & $\varepsilon 67.595$ \\
Machines & $\varepsilon 18.250$ \\
Purchasing & $\varepsilon 14.650$ \\
Sales and marketing & $\underline{\varepsilon 28.475}$ \\
Total Costs & $\varepsilon 128.970$ \\
\hline
\end{tabular}

The set-up, quality control, and reclaiming activities had no costs traced directly to them because the analysis revealed that they used resources from the production labour and - to a lesser extent from the machines activities categories.

As, ABCM requires the identification of cost drivers for each of the activities, Mr. van Schenkel has gathered all possible information for "process mapping". Process mapping means relating all activities with costs drivers in such a way that it becomes clear why and where resources such as machine and labour hours are consumed in the process of producing, marketing and selling the company's products. In other words, a process map shows the relationship of each activity to other activities and to the products and is the key instrument to determine product costs, cost drivers and capacity of each activity. Exhibit B provides you necessary monthly (and weekly) data about the resources consumed in the production process. It shows the result of this mapping process and indicates, where applicable, the capacity of each activity in terms of the selected cost driver.

Mr. van Schenkel now wants to determine the cost, cost drivers (output measures), and capacity of each activity, using the information available to him. The company's products were identified according to the number of colours printed on the shirt. Because the maximum number of colours printed was six, there were six unique products. The screen printing of six-colour T-shirts is significantly more complex than for one- and two-colour T-shirts. The six-colour T-shirt requires more production labour, more machine time, more set-up time, more quality control, and more reclaiming time. In addition, more purchase orders are required for the six-colour T-shirts.

\footnotetext{
${ }^{1}$ Weekly data are found in Appendix 1 or in file Duographic.xls (Exhibit B).
} 


\begin{tabular}{|c|c|c|c|c|c|c|c|}
\hline Month/Activity & Mach $^{2}$ & S-U $\mathbf{U}^{3}$ & Prod $^{4}$ & $S \& M^{5}$ & Purch $^{6}$ & $\operatorname{Recl}^{7}$ & $\mathbf{Q C}^{8}$ \\
\hline Cost driver: & MH & LH & LH & SO & PO & LH & $\mathrm{LH}$ \\
\hline January & 106 & 65,5 & 261,25 & 159 & 45 & 59,5 & 134,5 \\
\hline February & 108,5 & 63,5 & 262,75 & 153 & 44 & 61,5 & 127 \\
\hline March & 144,25 & 87 & 354,5 & 211 & 59 & 82,25 & 184 \\
\hline April & 174,5 & 102,25 & 423,5 & 247 & 70 & 99,25 & 221 \\
\hline May & 190 & 111,25 & 462,25 & 267 & 76 & 109,5 & 242,25 \\
\hline June & 197 & 115 & 479,79 & 276 & 79 & 114,5 & 251,25 \\
\hline July & 187 & 112 & 459 & 273 & 76 & 107,75 & 236,25 \\
\hline August & 180,25 & 106,5 & 440 & 257 & 73 & 103,25 & 230 \\
\hline September & 165,75 & 99,5 & 407 & 243 & 68 & 95 & 211,25 \\
\hline October & 155,5 & 92 & 379.75 & 222 & 63 & 89,5 & 198 \\
\hline November & 125,5 & 76 & 309 & 184 & 52 & 71,25 & 160,25 \\
\hline December & 209,75 & 122,75 & 514 & 297 & 84 & 112,5 & 268,5 \\
\hline \multicolumn{3}{|c|}{ Machine hours } & Labour & ours & \multicolumn{2}{|c|}{ Sales orders } & Purchase orders \\
\hline \multicolumn{2}{|l|}{ Capacity/year } & \multicolumn{2}{|l|}{4.160} & 9.600 & & 2.789 & 789 \\
\hline \multicolumn{8}{|l|}{ the year ende } \\
\hline
\end{tabular}

Normally, customers provide the blank T-shirts. If not, the company buys blank T-shirts and just charges the customers for them, without a mark-up. Thus, the only raw material used by the company is the ink. Exhibit $\mathrm{C}$ shows the ink used by each of the products.

\begin{tabular}{|c|c|}
\hline \multicolumn{2}{|c|}{$\begin{array}{c}\text { Exhibit C } \\
\text { DuoGraphic B.V. } \\
\text { Ink used in Screen Printing }\end{array}$} \\
\hline Product & Millilitres per unit product \\
\hline One-colour shirt & 1 \\
\hline Two-colour & 1 \\
\hline Three-colour & 1 \\
\hline Four-colour & 1,5 \\
\hline Five-colour & 2 \\
\hline Six-colour & 2 \\
\hline
\end{tabular}

The raw material (ink) is to treated as a direct cost. This means that the cost is incurred only as each product is actually produced. Concerning the cost drivers, the annual cost of the activity to which the driver is linked can be calculated. For example, the annual cost for machines is $\varepsilon 18.250$ per year (see exhibit A). The annual machine capacity is 4.160 (see exhibit B), expressed in terms of the cost driver for the activity, namely machine hours $(\mathrm{MH})$. The same holds for the production labour

\footnotetext{
2 Machine: cost driver machine hours (MH)

${ }^{3}$ Set-Up: cost driver: labour hours (LH)

${ }^{4}$ Production: cost driver: labour hours (LH)

${ }^{5}$ Sales \& Marketing: cost driver: customer sales orders (SO)

${ }^{6}$ Purchasing: cost driver: purchasing orders (PO)

${ }^{7}$ Reclaiming: cost driver: labour hours (LH)

${ }^{8}$ Quality control: cost driver: labour hours $(\mathrm{LH})$
} 
(PL) activity. It can be explained and traced to the products in the same way as the machine activity. The cost for the activity is 867.595 per year, the output measure or cost driver is the number of labour hours, and the annual capacity is 9.600 labour hours.

The reclaiming, set-up, and quality control activities are performed by the production labour activity. Therefore, these activities do not have their own annual cost and capacity. They have no cost of their own, and the capacity is limited by the capacity of the production labour activity.

Close examination of the reclaiming activity, i.e. cleaning the screens for re-use, shows that reclaiming has the number of reclaiming hours as cost driver. Note that every hour of reclaiming uses up one hour of production labour. In other words, reclamation capacity would be the total number of labour hours that are available during the year and every hour used up by the reclamation activity can no longer be used for production, set-up or quality control.

In the case of the machine and the production labour activity, the capacity represents the number of hours that reasonably can be expected to be available, given the estimated cost for the activity.

The specification of the capacities of the administrative activities (sales and marketing and purchasing) is more difficult. The reasoning usually follows these lines. Last year, if $\varepsilon 28.475$ was spent on sales and marketing (S\&M) and 2.789 sales orders were processed during that year. Hence, it would be difficult to argue that the capacity was less these 2.789 sales orders. On the other hand, it might be possible to argue that the capacity is much greater because there was unused capacity last year. To use last year's experience as the capacity is a conservative approach.

\section{Activity-Based Cost Management Model \& Theory of Constraints}

The information in exhibits $\mathrm{A}$ and $\mathrm{B}$ can be used to calculate the charging rates for each of the activities for which there are annual costs and annual capacities. The charging rates are the ratio of (annual) cost/capacity for each activity. Together with the information given in exhibits D-1 and D2 , these charging rates can then be used to create an income statement showing product profitability based on the extent to which each product makes use of the various activities in the process.

\begin{tabular}{|cc|}
\hline \multicolumn{3}{|c|}{ Exhibit D-1 } \\
DuoGraphic B.V. \\
Sales \\
Product & \\
\hline
\end{tabular}




\begin{tabular}{|lll|}
\hline 1-clr & 36.000 & $\varepsilon 73.800$ \\
2-clr & 9.000 & $\varepsilon 32.400$ \\
$3-\mathrm{clr}$ & 6.000 & $\varepsilon 19.500$ \\
$4-\mathrm{clr}$ & 2.400 & $\varepsilon 8.640$ \\
$5-\mathrm{clr}$ & 1.800 & $\varepsilon 4.725$ \\
$6-\mathrm{clr}$ & 4.800 & $\underline{\varepsilon 14.225}$ \\
& $\mathbf{6 0 . 0 0 0}$ & $\mathbf{\varepsilon 1 5 3 . 2 9 0}$ \\
Total & \\
\hline \multicolumn{2}{l}{ Note: These figures reflect actual sales for the past year. } \\
\end{tabular}

\begin{tabular}{|c|c|c|c|c|c|c|}
\hline \multirow[b]{2}{*}{ Month } & \multirow[b]{2}{*}{ 1-clr } & \multicolumn{3}{|c|}{$\begin{array}{c}\text { Exhibit D-2 } \\
\text { DuoGraphic B.V. } \\
\text { Sales - Monthly Details }\end{array}$} & \multirow[b]{2}{*}{ 5-clr } & \multirow[b]{2}{*}{ 6-clr } \\
\hline & & 2-clr & 3-clr & 4-clr & & \\
\hline January & 2.250 & 470 & 315 & 130 & 105 & 225 \\
\hline February & 1.900 & 535 & 355 & 135 & 100 & 260 \\
\hline March & 2.800 & 660 & 440 & 180 & 125 & 350 \\
\hline April & 3.050 & 855 & 570 & 230 & 150 & 425 \\
\hline May & 3.350 & 875 & 580 & 265 & 185 & 470 \\
\hline June & 3.450 & 895 & 600 & 255 & 205 & 500 \\
\hline July & 3.580 & 885 & 590 & 120 & 195 & 485 \\
\hline August & 3.300 & 830 & 555 & 250 & 160 & 440 \\
\hline September & 3.240 & 745 & 495 & 210 & 155 & 395 \\
\hline October & 2.850 & 725 & 480 & 195 & 150 & 380 \\
\hline November & 2.480 & 575 & 385 & 165 & 105 & 295 \\
\hline December & 3.750 & 950 & 635 & 265 & 165 & 575 \\
\hline Total & 36.000 & 9.000 & 6.000 & 2.400 & 1.800 & 4.800 \\
\hline
\end{tabular}

Goldratt (1992) has stated that the goal of a company is to make money now and in the future. He introduces three operational measures-throughput, operating expense, and inventory-to provide feedback to operations management as they seek to make operating decisions that will enhance profits, cash flow, and return on assets.

Goldratt defines throughput as the revenue minus the cost of the raw materials based on the number of units sold (not produced). He defines operating expense as those expenses incurred to convert raw materials to throughput. Thus, he regards all expenses other than raw materials as operating

\footnotetext{
${ }^{9}$ For weekly data, see appendix 2 or file Duographic.xls (Exhibit D).
} 
expenses. Inventory represents the cost of all the raw materials that have not yet been sold plus the cost of the more traditional assets that are used in the business (plant and equipment).

The foregoing is a simplified version of Goldratt's definition. He would deduct more than just raw materials from revenues to arrive at throughput. He would deduct any resource that is purchased on an as-needed basis and not acquired in lump sum in advance of its use. Thus, in Goldratt's view, labour is not treated like raw materials. Instead, labour is regarded as an operating expense because a company typically purchases labour services in a lump sum, and, if the services are not used, the company has paid for the services anyway.

In Goldratt's view, a process is a series of dependent events (activities), and the goal is the maximization of the process throughput. The primary challenge to maximizing the throughput is in identifying the activity or activities that are the constraints to throughput. Once the constraining activity or activities have been identified, five steps of focusing attempt to increase the throughput without increasing operating expense or increasing inventory.

\section{The Focus on Management}

The first step is to identify constraints. At DuoGraphic, we have to keep in mind that the purchasing and the sales $\&$ marketing activities are soft constraints because of the manner in which their capacities were determined. At this first step, the company's TOC throughput net income before taxes can be calculated.

The second step involves exploiting the binding constraints in order to squeeze the most throughput out of the resources paid for by the operating expenses. DuoGraphic B.V. optimised net income in the computer model to determine the optimal product mix. The model specified that the unused capacity of each activity had to be greater than or equal to zero. Thus, the model optimisation recognized that the use of the activities to produce and sell products cannot exceed the capacity of the activity.

The optimisation suggested a slight change in the product mix would increase throughput and net income before taxes. The optimised model suggested that at the new product mix, the labour production activity and the sales and marketing activity would have no unused capacity. The machines activity would have much unused capacity, and the purchasing activity would have just a small amount of unused capacity. 
The third step of focusing is subordination. In this step, activities are examined in light of unused capacity to determine if they could be used to help out other activities with no unused capacity. By examining the configuration of the machines, the consulting team was able to identify an opportunity for subordination. By rearranging the process layout, the production labourers would not have to interrupt their workflow to walk from one machine to another. This rearrangement of the machines permitted the reduction of all production labour factors by .07 (approximately 30 seconds per shirt). This subordination of machines to production labour created some unused capacity in the production labour activity. Given the same product mix, the only remaining activity with no unused capacity was sales and marketing.

The fourth step of focusing is elevation. Here additional capacity is acquired either by increasing operating expense, increasing inventory, or both. The consulting team realized that in order to increase throughput and profits, the company would have to increase the capacity of the sales and marketing activity by hiring a person who could work in both the sales and marketing activity and the purchasing activity. The cost and the capacity of the sales and marketing and the purchasing activities were increased to reflect this elevation. An optimisation of the model revealed that all of the activities except the production labour activity had significant unused capacities. The result was a slight change in the suggested product mix, an increase in the throughput and an increase in net income before taxes. At this optimisation it was clear that the production labour activity had only a small amount of unused capacity. The production labour activity would have to be elevated in order to take full advantage of the additional sales and marketing resources.

Goldratt specified a fifth step of focusing that he labelled inertia. He warned that there is a tendency to stop the process when the results have been so rewarding that managers would tend to rest on their laurels. He explained that there always will be a constraint that limits the throughput of the process. Sometimes the constraint will be a physical constraint (as was the situation in this case), sometimes a market constraint, and sometimes a policy constraint ("That's the way we have always done it."). Inertia is overcome by repeating the steps. At DuoGraphics B.V., the consulting team chose to elevate the production labour activity by recommending the hiring of two additional production workers. The model indicated that all of the activities would have unused capacity given the most recently suggested product mix. The consulting team suggested that the newly hired person in the sales and marketing activity attempt to expand the market by $20 \%$ by concentrating on a nearby metropolitan area, one in which the company had never had any sales. At this point, the consulting team also modified the optimal sales mixes suggested by the computer. 


\section{$\underline{\text { Strategic Marketing Considerations }}$}

Optimisation is a tactical tool for evaluating the use of resources from a short-term perspective. Although the team used the optimisation results to suggest a product mix to best utilize the resources, the team was aware of another important consideration revealed by the $\mathrm{ABCM}$ information (see requirement 2). The analysis showed that five-colour and the six-colour T-shirts have a negative net income per unit. Thus, the cost of direct materials and the activities used to produce those two products is greater than the selling price of each of the products. The consulting team urged the company to consider raising the price or further improving the process. If neither of those alternatives were feasible, the advice was to consider replacing the two unprofitable products by increasing the sales of the profitable products. The company chose to continue offering the fivecolour and six-colour T-shirts in order to be considered a full-service screen printer: some traditional customers for the other T-shirts often buy the five-colour and six-colour T-shirts. If necessary, however, they were willing to quote higher prices for those types of T-shirts in order to eliminate any unprofitable orders that were for those types of T-shirts only. In a sense, the fivecolour and six-colour T-shirts are loss leaders for customers who buy large quantities of the other shirts. The consulting team learned that the owners of the company had never given any serious thought to the relative profitability of the various products. The $\mathrm{ABCM}$ presentation caused them to rethink their pricing policies and their marketing strategies.

The use of Goldratt's TOC and the five steps of focusing was guided by the information contained in a management accounting report that was prepared using ABCM principles. The unused capacity information for each activity provided the information necessary for TOC. Additionally, the use of the capacities of the activities permitted both the isolation of unused capacities and the stabilization of product costs in the face of changing production quantities. The ABCM-oriented report also permits the reporting of several measures of performance that are important to TOC -throughput, operating expense, and profit.

A comprehensively integrated set of financial reports also would permit the reporting of the other three measures of performance -inventory, cash flow, and return on assets. That information could be integrated easily with the addition of a pro forma cash flow statement and a pro forma balance sheet that is integrated with the ABCM-oriented product income statement. In addition to providing information for $\mathrm{TOC}$ and process improvement, the $\mathrm{ABCM}$ management accounting report provides information on unused capacities of activities and the relative profitability of the product 
offerings. As DuoGraphic B.V. discovered, this information is valuable in developing marketing strategies.

\section{$\underline{\text { Requirements }}$}

1.Construct a table summarising all activities together with the cost driver per activity and,

2. Closely examine exhibits D-1 and D-2. Comment on your findings.

3. Construct an income statement for the year ended showing product profitability based on the extent to which each product makes use of the various activities in the process (ABC). Also calculate TOC throughput and throughput per unit. Calculate unused capacity and its euroequivalent, as suggested by Cooper \& Kaplan (1992). Finally, discuss the main difference with $\mathrm{ABC}$ and traditional volume-based costing.

4. Having calculated the "connectors", try to come to the profit maximising product-mix. In other words, if you were the manager, and given the capacity constraints of the year ended, how would you try to change the product-mix? How would you set-up a sales and pricing (marketing) strategy that would enhance profitability? 


\section{$\underline{\text { References }}$}

Cooper, R. \& R. S. Kaplan, 1992, "Activity-Based Systems: Measuring the Costs of Resource Usage", Accounting Horizons, Sept 92, pp. 1-13

Goldratt E.M. \& J. Cox, 1992, The Goal: A Process of Ongoing Improvement, 2nd (revised) edition, North River Press, Inc., Croton-on Hudson, N.Y.

Baxendale, S. J. \& M. Gupta, 1998, Aligning TOC \& ABC for Silkscreen Printing, Management Accounting, April '98, pp. 39-44

Baxendale, S. J. \& M. Gupta, 1997, "Integrating TOC and ABCM in a Healthcare Company," Journal of Cost Management, July/August.

Campbell, R., 1997, Designing an Information System using ABC and TOC, Journal of Cost Management (11), pp. 16-

Cooper, R. \& R. Slagmulder, 1999, Strategic Cost Management: Integrating ABC and TOC, Management Accounting, February 1999, pp. 20-21

Demmy, S. \& J. Talbot, 1998, Improve Internal Reporting with Activity-based Costing and Theory of Constraints, Management Accounting, November 1998, pp. 18-24

Goldratt, E.M. \& R. Fox, 1989, Chapter 4, "The Importance of a Systems Constraint", The Theory of Constraints Journal, Vol.1, February 1989, pp. 5-7.

Kee, R., 1997, Integrating ABC with the TOC to enhance production-related decisionmaking, Accounting Horizons (9), pp. 48-52

Holmen, J., 1995, ABC vs. TOC: It's a Matter of Time, Management Accounting, January 1995, pp. 37-40

Noreen, E. , D. Smith \& J.T. Mackey, 1995, The Theory of Constraints and Its Implications for Management Accounting, The North River Press, Great Barrington (MA), p. 24

Vergauwen, P., 2002, Integrating ABC \& TOC to Improve Internal Reporting: Isle of Arran Distillers, a Case Study, MARC Working paper, Universiteit Maastricht, 14p. 


\section{Appendix 1: Weekly Data Cost Drivers}

\begin{tabular}{|c|c|c|c|c|c|c|c|c|}
\hline Mon & Wk & MACH(H) & SU(LH) & PROD(LH) & S\&M & PURCH $^{10}$ & RECL(LH) & QC(LH) \\
\hline \multirow[t]{4}{*}{ Jan } & 1 & 23 & 17 & 56,75 & 41 & 45 & 9 & 26,25 \\
\hline & 2 & 19,25 & 14,25 & 47,75 & 35 & & 8 & 22,25 \\
\hline & 3 & 19 & 13,75 & 49 & 34 & & 9,5 & 24,25 \\
\hline & 4 & 44,75 & 20,5 & 107,75 & 49 & & 33 & 61,75 \\
\hline \multirow[t]{4}{*}{ Feb } & 1 & 20,25 & 13,25 & 51,25 & 33 & 44 & 10,75 & 26,75 \\
\hline & 2 & 27,5 & 16,25 & 69,5 & 40 & & 16,75 & 27,25 \\
\hline & 3 & 35 & 18 & 82,75 & 42 & & 22,25 & 44,25 \\
\hline & 4 & 25,75 & 16 & 59,25 & 38 & & 11,75 & 28,75 \\
\hline \multirow[t]{4}{*}{ Mrt } & 1 & 38,75 & 22,5 & 93,75 & 54 & 59 & 22,25 & 48,75 \\
\hline & 2 & 42,25 & 23,5 & 101 & 56 & & 26,25 & 53,5 \\
\hline & 3 & 36,5 & 22,5 & 91,75 & 55 & & 21 & 47,25 \\
\hline & 4 & 26,75 & 18,5 & 68 & 46 & & 12,75 & 34,5 \\
\hline \multirow[t]{4}{*}{ Apr } & 1 & 53 & 27,5 & 129,25 & 67 & 70 & 37 & 70 \\
\hline & 2 & 37,5 & 25 & 87,25 & 59 & & 15 & 41,25 \\
\hline & 3 & 41,75 & 25 & 104,5 & 61 & & 24,5 & 54,25 \\
\hline & 4 & 42,25 & 24,75 & 102,25 & 60 & & 22,75 & 55,5 \\
\hline \multirow[t]{4}{*}{ May } & 1 & 51,5 & 29,75 & 132,75 & 73 & 76 & 34,25 & 70,25 \\
\hline & 2 & 55,5 & 30 & 131,75 & 72 & & 33,5 & 71,25 \\
\hline & 3 & 42,25 & 26,5 & 100 & 63 & & 20,25 & 51,5 \\
\hline & 4 & 40,75 & 25 & 97,75 & 59 & & 21,5 & 49,25 \\
\hline \multirow[t]{4}{*}{ Jun } & 1 & 56,5 & 30,25 & 134 & 72 & 79 & 34,75 & 73,5 \\
\hline & 2 & 54,75 & 29,5 & 129,75 & 70 & & 33,5 & 70 \\
\hline & 3 & 44,5 & 27,75 & 112,25 & 67 & & 25,5 & 56,75 \\
\hline & 4 & 41,25 & 27,5 & 103,75 & 67 & & 20,75 & 51 \\
\hline \multirow[t]{4}{*}{ Jul } & 1 & 35,25 & 28 & 91,25 & 71 & 76 & 13,75 & 41,5 \\
\hline & 2 & 41 & 25 & 99,25 & 61 & & 21,75 & 49,75 \\
\hline & 3 & 82,75 & 36,75 & 196,25 & 85 & & 60,75 & 112 \\
\hline & 4 & 28 & 22,25 & 72,25 & 56 & & 11,5 & 33 \\
\hline \multirow[t]{4}{*}{ Aug } & 1 & 42,5 & 26 & 107,75 & 65 & 73 & 26,25 & 56,75 \\
\hline & 2 & 32,75 & 24,5 & 81,25 & 60 & & 12,5 & 37,5 \\
\hline & 3 & 46,25 & 26,75 & 113,75 & 64 & & 27 & 58,75 \\
\hline & 4 & 58,75 & 29,25 & 137,25 & 68 & & 37,5 & 77 \\
\hline \multirow[t]{4}{*}{ Sep } & 1 & 60,25 & 29,5 & 144,25 & 70 & 68 & 41,25 & 80,5 \\
\hline & 2 & 45,25 & 24 & 108,75 & 57 & & 29,5 & 60 \\
\hline & 3 & 32,25 & 23 & 79,75 & 57 & & 13 & 37,25 \\
\hline & 4 & 28 & 23 & 74,25 & 59 & & 11,25 & 33,5 \\
\hline \multirow[t]{4}{*}{ Oct } & 1 & 43,75 & 24,75 & 108,25 & 60 & 63 & 28,75 & 58,75 \\
\hline & 2 & 29,75 & 20,5 & 72,75 & 50 & & 12,75 & 34,5 \\
\hline & 3 & 40,5 & 23,25 & 100,25 & 56 & & 25,75 & 52,5 \\
\hline & 4 & 41,5 & 23,5 & 98,5 & 56 & & 22,25 & 52,25 \\
\hline \multirow[t]{4}{*}{ Nov } & 1 & 31,5 & 17,75 & 77,75 & 43 & 52 & 21 & 40,75 \\
\hline & 2 & 36,25 & 23,5 & 85,25 & 56 & & 14 & 40,5 \\
\hline & 3 & 28,75 & 17,25 & 72,25 & 42 & & 18 & 39 \\
\hline & 4 & 29 & 17,5 & 73,75 & 43 & & 18,25 & 40 \\
\hline \multirow[t]{4}{*}{ Dec } & 1 & 49,75 & 29,5 & 119 & 70 & 84 & 25,25 & 59 \\
\hline & 2 & 55,75 & 32,5 & 133,5 & 76 & & 29,5 & 68,5 \\
\hline & 3 & 51 & 30,5 & 127,5 & 76 & & 31,25 & 66 \\
\hline & 4 & 53,25 & 30,25 & 134,25 & 75 & & 26,5 & 75 \\
\hline
\end{tabular}

\footnotetext{
${ }^{10}$ Only monthly data are available.
} 


\section{Appendix 2: Weekly Sales Data Colour Shirts}

\begin{tabular}{|c|c|c|c|c|c|c|c|c|c|c|c|c|c|}
\hline \multirow{2}{*}{$\frac{\text { Mon }}{\text { Jan }}$} & \multicolumn{2}{|l|}{ Wk } & \multicolumn{2}{|l|}{ 1-clr } & \multicolumn{2}{|l|}{ 2-clr } & \multicolumn{2}{|l|}{ 3-clr } & \multicolumn{2}{|l|}{ 4-clr } & \multicolumn{2}{|l|}{ 5-clr } & \multirow{2}{*}{$\frac{\text { 6-clr }}{225}$} \\
\hline & 1 & 650 & 2.250 & 200 & 470 & 125 & 315 & 0 & 130 & 0 & 105 & 0 & \\
\hline & 2 & 600 & & 75 & & 150 & & 0 & & 0 & & 0 & \\
\hline & 3 & 600 & & 100 & & 40 & & 30 & & 0 & & 25 & \\
\hline & 4 & 400 & & 95 & & 0 & & 100 & & 105 & & 200 & \\
\hline \multirow[t]{4}{*}{ Feb } & 1 & 525 & 1.900 & 125 & 535 & 0 & 355 & 75 & 135 & 0 & 100 & 30 & 260 \\
\hline & 2 & 550 & & 150 & & 0 & & 60 & & 0 & & 100 & \\
\hline & 3 & 400 & & 75 & & 180 & & 0 & & 50 & & 130 & \\
\hline & 4 & 425 & & 185 & & 175 & & 0 & & 50 & & 0 & \\
\hline \multirow[t]{4}{*}{ Mrt } & 1 & 650 & 2.800 & 125 & 660 & 200 & 440 & 40 & 180 & 25 & 125 & 100 & 350 \\
\hline & 2 & 675 & & 100 & & 150 & & 40 & & 100 & & 100 & \\
\hline & 3 & 750 & & 200 & & 90 & & 20 & & 0 & & 125 & \\
\hline & 4 & 725 & & 235 & & 0 & & 80 & & 0 & & 25 & \\
\hline \multirow[t]{4}{*}{ Apr } & 1 & 750 & 3.050 & 200 & 855 & 0 & 570 & 30 & 230 & 150 & 150 & 200 & 425 \\
\hline & 2 & 775 & & 200 & & 375 & & 0 & & 0 & & 0 & \\
\hline & 3 & 800 & & 200 & & 125 & & 25 & & 0 & & 150 & \\
\hline & 4 & 725 & & 255 & & 70 & & 175 & & 0 & & 75 & \\
\hline \multirow[t]{4}{*}{ May } & 1 & 1.000 & 3.350 & 255 & 875 & 0 & 580 & 0 & 265 & 0 & 185 & 275 & 470 \\
\hline & 2 & 750 & & 250 & & 125 & & 125 & & 100 & & 125 & \\
\hline & 3 & 825 & & 250 & & 175 & & 125 & & 50 & & 0 & \\
\hline & 4 & 775 & & 120 & & 280 & & 15 & & 35 & & 70 & \\
\hline \multirow[t]{4}{*}{ Jun } & 1 & 775 & 3.450 & 120 & 895 & 200 & 600 & 150 & 255 & 100 & 205 & 125 & 500 \\
\hline & 2 & 750 & & 150 & & 200 & & 105 & & 105 & & 125 & \\
\hline & 3 & 950 & & 225 & & 150 & & 0 & & 0 & & 150 & \\
\hline & 4 & 975 & & 400 & & 50 & & 0 & & 0 & & 100 & \\
\hline \multirow[t]{4}{*}{ Jul } & 1 & 1.250 & 3.580 & 400 & 885 & 50 & 590 & 0 & 120 & 0 & 195 & 0 & 485 \\
\hline & 2 & 750 & & 300 & & 140 & & 0 & & 45 & & 85 & \\
\hline & 3 & 550 & & 0 & & 280 & & 120 & & 150 & & 400 & \\
\hline & 4 & 1.030 & & 185 & & 120 & & 0 & & 0 & & 0 & \\
\hline \multirow[t]{4}{*}{ Aug } & 1 & 975 & 3.300 & 185 & 830 & 0 & 555 & 75 & 250 & 60 & 160 & 115 & 440 \\
\hline & 2 & 950 & & 375 & & 105 & & 0 & & 0 & & 0 & \\
\hline & 3 & 750 & & 250 & & 175 & & 0 & & 0 & & 175 & \\
\hline & 4 & 625 & & 20 & & 275 & & 0 & & 0 & & 0 & \\
\hline \multirow[t]{4}{*}{ Sep } & 1 & 650 & 3.240 & 0 & 745 & 250 & 495 & 100 & 210 & 75 & 155 & 250 & 395 \\
\hline & 2 & 675 & & 0 & & 175 & & 110 & & 80 & & 125 & \\
\hline & 3 & 810 & & 445 & & 50 & & 0 & & 0 & & 20 & \\
\hline & 4 & 1.105 & & 300 & & 20 & & 0 & & 0 & & 0 & \\
\hline \multirow[t]{4}{*}{ Oct } & 1 & 850 & 2.850 & 0 & 725 & 120 & 480 & 95 & 195 & 75 & 150 & 125 & 380 \\
\hline & 2 & 700 & & 300 & & 125 & & 0 & & 0 & & 25 & \\
\hline & 3 & 725 & & 125 & & 120 & & 0 & & 50 & & 150 & \\
\hline & 4 & 575 & & 300 & & 115 & & 100 & & 25 & & 80 & \\
\hline \multirow[t]{4}{*}{ Nov } & 1 & 600 & 2.480 & 0 & 575 & 125 & 385 & 0 & 165 & 75 & 105 & 100 & 295 \\
\hline & 2 & 575 & & 575 & & 100 & & 0 & & 0 & & 25 & \\
\hline & 3 & 650 & & 0 & & 75 & & 80 & & 30 & & 75 & \\
\hline & 4 & 655 & & 0 & & 85 & & 85 & & 0 & & 95 & \\
\hline Dec & 1 & 725 & 3.750 & 400 & 950 & 250 & 635 & 0 & 265 & 0 & 165 & 125 & 575 \\
\hline & 2 & 800 & & 400 & & 250 & & 35 & & 0 & & 150 & \\
\hline & 3 & 1.100 & & 150 & & 135 & & 30 & & 65 & & 150 & \\
\hline & 4 & 1.125 & & 0 & & 0 & & 200 & & 100 & & 150 & \\
\hline
\end{tabular}

